\title{
2. オリンピック放送システム
}

川崎 明 ${ }^{\dagger}$, 正会員 矢 野保 夫 $^{\dagger+}$

\section{2-1 IBC （国際放送センタ）}

\section{1. まえがき}

IBC (International Broadcast Center) はメインス タジアム等のある「モジュイックの丘」の麓, カタル 一ニア美術館からスペイン広場に至る, 広く美しい道 路に面したバルセロナ貿易フェア館に臨時に設備され た（写真 1).

ロケーションとしては, メインスタジアムに近くメ インプレスセンタも続きの建物にあり, 理想的な場所 であった。

\section{2. 概 要}

IBC 内の RTO (Radio Televisio Olimpica) の設備 では各競技場から送られて来た国際映像, 各国が制作 したユ二映像, それらに伴う音声を受信し各海外局設 備に分配, 各局が加工したものを再び受け取り, 衛星 地上局や国内回線に送出した。

IBC はホスト局 RTOにとって, 放送権を持った各 海外局へ国際映像および音声を受渡しする責任分界点 であり，150に及ぶ海外局の設備のサポートおよび送 出心臓部といえる所である。建物は以下の 3 層に分か れている。

地下 1 階 (Basement) : 日本 (BOJP) とオーストラ リアが占めた。

1 階（Ground Floor）：表通りにあたり，NHKの $1125 \mathrm{HDTV}$ とBUのユーレカ 1250

\footnotetext{
$†$ 株式会社東京放送 国際ニュースセンター

†† 日本テレビ放送網株式会社 制作技術局

“2. International Broadcast Center" by Akira Kawasaki (Department of International News Center, Tokyo Broadcasting System, Inc., Tokyo) and Yasuo Yano (Technical Operation Center, Nippon Television Network Corp., Tokyo)
}

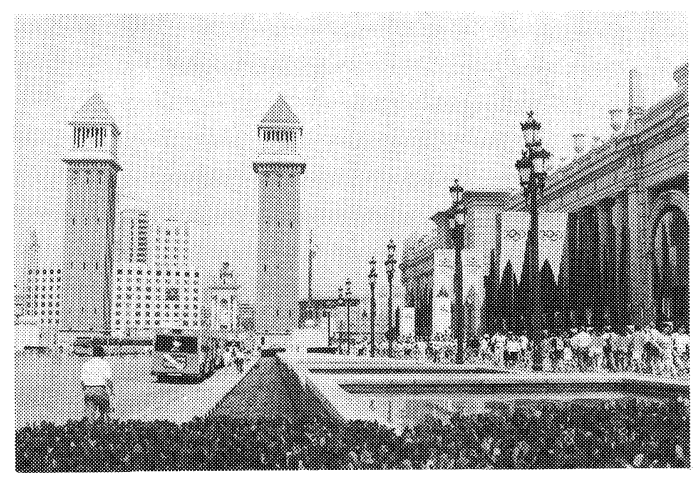

写真 1 IBC

HDTVが相対して切れのよい大画面のデモ を行い，人気を集めていた。

2 階とギャラリー (First Floor と Galleries)：RTO のオペレーションルームと数多くの海外施設 が設置された。
IBC の総床面積
$45000 \mathrm{~m}^{2}$
BOJP の床面積
$2400 \mathrm{~m}^{2}$
IBC の RTO スタッフ
600 名
設備を作った海外局
120

\section{IBC の設備と機能}

ホスト局 RTOは, 次に述べる設備を IBC 内に作 りオペレーションを行った. 図 1 にIBC 内全体の信 号の流れを示す.

\section{1 テルコルーム (Telco room)}

各競技場と IBCの間は, 図 2 に示すように映像お よび音声伝送用の回線ネットワークを組んだ。

回線は殆んどオリンピックのために新設したもの で, ディジタル化が積極的になされていた.

ディジタル光ファイバ回線には Alcatel STA 社製

(15) 1545 


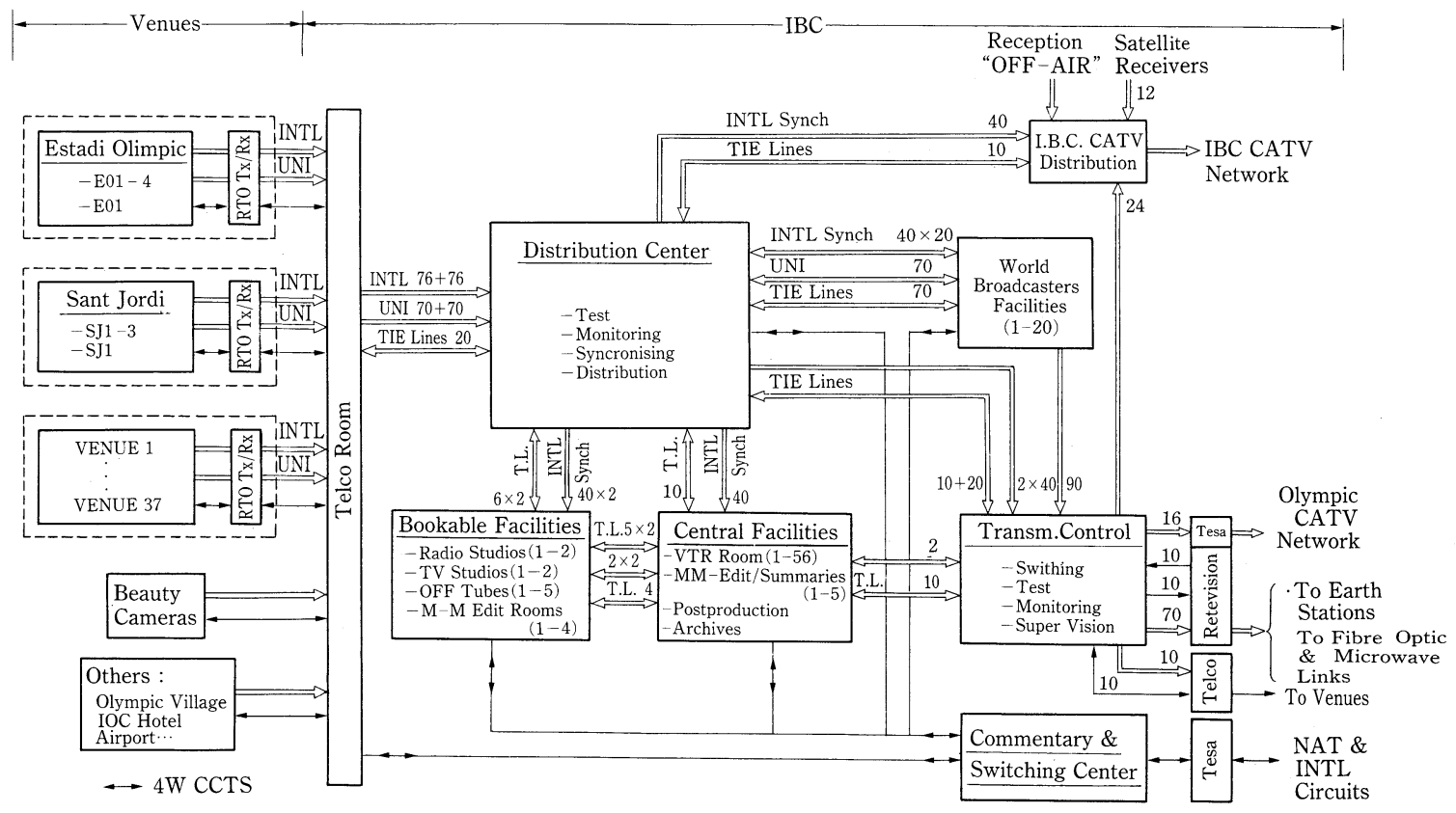

図 1 ゼネラルブロックダイヤグラム

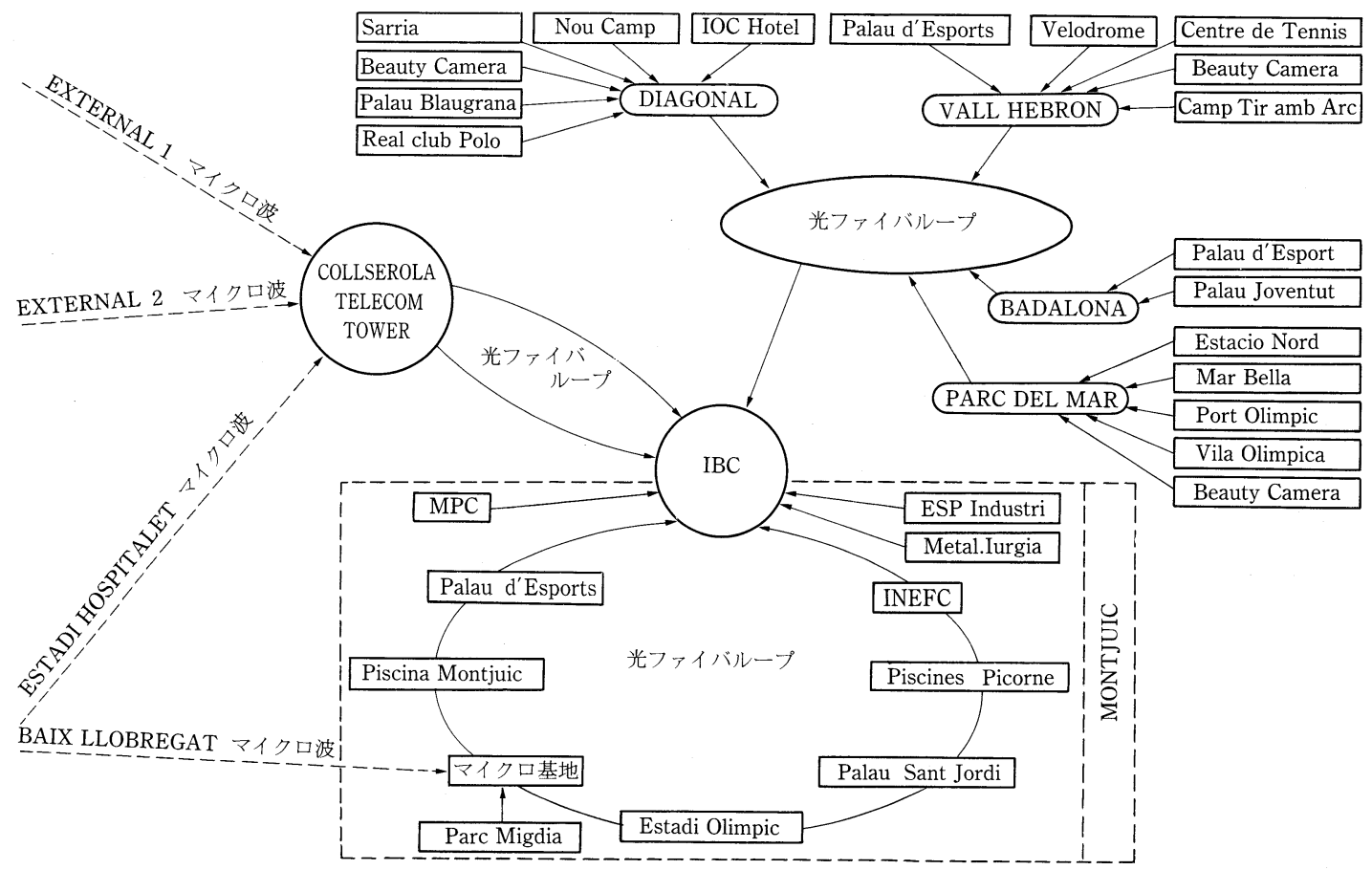

図 2 光ファイバ抢よびマイクロウェーブ網概念図

OVID-4 HQ (シングルモード) が使用された。これは 1 回線に映像 4 チャンネル伝送可能である. マイクロ固定回線にはディジタル式 $(140 \mathrm{Mb} / \mathrm{s})$
Telettra Espanola SA 社製のものが使用された。1 回線に同じく映像 4 チャンネル伝送可能である.移動 マイクロウェーブ回線はアナログで Alcatel 社製 TM 


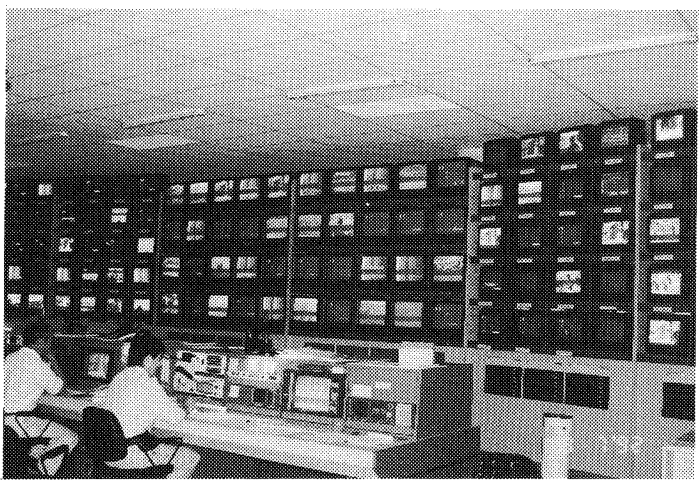

写真 2 ディストリビューションセンタ

-400を使い, ネットワークが組まれていた。なお光 ファイバは全中継回線の $85 \%$ を占め, 全長 $578 \mathrm{~km}$ 布 線された.テルコルームで受信した信号はデコードし た後, ディストリビューションセンタに渡された。

なお, 回線のオペレーションは伝送会社のTelephonica 社, Retevision 社が共同で行った.

\section{2 ディストリビューションセンタ (写真 2)}

テルコルーム経由で受けた 44 以上にわたる各競技 場からの信号は, 波形等化した後, フレームシンクロ ナイザで同期結合をとり，海外局および RTO 設備に 分配した。

すべての映像信号には送出場所がわかるように ID 信号が V ブランキングの中に插入してあり，デコー ダ付きモニタで画面内に ID を表示させ, 誤操作を防 ぐようになっていた。

入力数：国際映像および音声 76 ユ二映像および音声 56

分配先：海外放送局設備 20 RTO 関連 12

\section{3 センタ設備}

$\begin{array}{lrr}\text { VTR 室 } & \text { D 3 } & 50 \text { 台 } \\ \text { VTR 編集室 } & 3 \text { 室 } \\ \text { ポストプロルーム } & 1 \text { 室 }\end{array}$

ディストリビューションセン夕経由で送られくる各 競技場の国際映像と音声は, すべてこのVTR 室で D 3 ディジタル VTRに収録された。

素材は大会記録保存用，およびライブラリー用とし て海外局も利用でき，毎日配信されるダイジェスト版 の制作もここで行われた。

\section{4 貸出設備}

$\begin{array}{ll}\text { スタジオ (2 カメラ) } & 2 \\ \text { VTR 編集室( 2 VTR) } & 4 \\ \text { オフチューブブース(コメボックス付) } & 4\end{array}$

以上の設備が用意されており，いずれもオンライン で使用でき, ブッキングオフィスで予約をとり有料で 借用できるようになっていた。

設備数は多くないが，オフライン機器しか設置して ない演外局とか, ピーク時オーバフローした局とかが 借用していた。

\section{5 トランスミッションコントロール}

IBC から送り出されるすべての信号は，このコン トロールルームで監視され，伝送スケジュールに従い 送出された.

IBC と地球局間はいずれもローカル回線網と同じ ディジタル光ファイバ回線で結ばれ，世界各地の放送 局へは, スペイン国内の地球局, バルセロナに近いペ ネデス，マドリッドに近いブイトラゴ，セゴビヤに近 いアルムラの 3 力所の地球局から衛星伝送された. 国 際テレビ伝送回線は 57 回線用意された。

日本向けの 4 チャンネルの伝送はすべてべネデス地 球局からインド洋上, 東経 $66^{\circ}$ のインテルサットに送 信, KDD 山口で受信した。

\section{6 コメンタリースイッチングセンタ}

映像はホスト局制作の国際映像が各海外局の共通映 像となるが, 音声は言葉が異なるので, 各国のコメン テータが各競技場で実況中継する。

これらの伝送および連絡に使う 4 ワイヤ音声回線 は, 合わせて 2200 回線以上になり,すべてこのセン 夕を経て接続され，当セン夕が調整および運用にあた つた。

誤操作を防ぐため，音声にもIDを使用した．

\section{7 CATV サービス}

IBC 内の CATV チャンネルは 72 チャンネルの充 分な容量を持ち，海外局のオーダも受けた。

ジャパンプールも日本への伝送, 全 5 チャンネルの 映像，音声を CATVに伝送，プールおよびユニの運 用に用いた。

メインスタジアムを含む一部の競技場では，この CATV サービスがあり，コメンテータ席でもジャパ ンプール伝送のプログラムを見ることができたので， 運用上助かった。

\section{8 ブッキングオフィス}

技術的な運用部門ではないが，各海外局から RTO に対するオーダおよびリクエストを受け, 担当者から 答を引き出して回答し, 料金も精算していくセクショ ンである。

2 年前の交渉の時点でブッキング作業が始まり，す でにこの時オフィスが機能しており，息の長いつき合 いとなった。 


\section{4. むす び}

降らないはずの雨が降り, 雨が降ると停電が起こ り, あちこちの海外局で 3 相電源のニュートラルに過 大な電流が流れ, こわいもの続きの電源であったが, 肝心なところではよく持ちこたえてくれた。

ブッキングオフィスに日本テレビの尉斗氏がスカウ トされ，日本テレビが快く派遣したこともジャパンプ ールのスムーズな運用の一助となった．

RTO が大担に新しいディジタル回線や D 3 ディジ タルVTR を採用していく積極的な姿勢には，日本人
にはない国民性を感じた。

次のアトランタでは, 今回アナログで残った衛星回 線や, IBC 内伝送, 受け渡しもディジタル化される のであろうか．そしてハイビジョンがどこまで伸びて いるだろうか.

競技もパフォーマンスも素晴らしかった。

ただ，運用は放送，セキュリティ，交通，すべての 部門において横のつながりが弱く, 混乱を来たした.

これも, どこにエネルギーを注ぐかという視点の違 いだったと受けとるべきかもしれない.

(川崎)

\section{2-2 競 技 中 継}

\section{1. まえがき}

バルセロナオリンピックは, 史上最大規模といわれ たソウル大会をしのぐ 28 競技 ( 3 競技はデモンストレ ーション種目)が 44 の競技場で行われ，全世界に中継 された，そのほとんどを生中継でカバーし，ENGで のカバーはごく一部の競技に限られた。この中継は， TVE，TV 3 等のスペインチームと EBU が中心とな って作られた混成チームである「RTO’92」により制 作，分配された。

オリンピック競技中継の規模は競技数, 参加国の増 加などから，ますます大きくなり，各競技の制作に対 する要求は多彩かつ，細かくなってきている．最近の ようにテレビによるスポーツ中継がこれほど盛んにな ると, より高品質, より効果的な映像作りや音声制作 が求められ，新しい発想による斬新なショットや映像 効果を作り出すことが必要となってきた。

「RTO’92」は，各競技制作をそれぞれ経験の深い 各国のテレビ局との共同体制で，これらの要求に対応
した．陸上競技場のスタンド屋根の下に設けられた高 速移動カメラや水泳競技で活躍した水中移動カメラの 開発はその一例である。ここに，今回のオリンピック の競技中継の概要を紹介する。

ほとんどの競技が生中継で制作，分配されたが，そ のうち陸上競技と今回のオリンピックで初めて生中継 で分配されたヨット競技について，その概略を紹介す る.

\section{2. 陸 上 競 技}

陸上競技はバルセロナ市の南西に位置する小高い丘 陵地モンジュイックにある Estadi Olimpicで 9 日間 行われた。同時進行で行われるフィールド，トラック 競技および国際映像を並行して制作するために， Estadi Olimpic には 5 つのプロダクションが設けら れた. 各出力はコンパウンド内の各国ユニラテラルキ ヤビンおよび光ケーブル網を経由して IBC 内各局へ 分配された．各プロダクションの担当局と制作競技お よび主な機器構成を表 1 に示す。

表 1 各プロダクションの担当局と制作競技および主な機器

\begin{tabular}{|c|c|c|c|c|c|}
\hline プロダクション & 1 & 2 & 3 & 4 & $\begin{array}{l}\text { 国際映像制作* } \\
\text { Integrated } \\
\text { Control }\end{array}$ \\
\hline 担当 & RTVE & RTVE & YLE & CCRTV & YLE \\
\hline 競技 & トラック競技 & $\begin{array}{l}\text { 円盤投げ, ハンマー投 } \\
\text { げ, 槍投げ, 砲丸投げ }\end{array}$ & $\begin{array}{l}\text { 走り高飛び, 棒高飛び, } \\
\text { 男女マラソン, 競歩 }\end{array}$ & $\begin{array}{l}\text { 走り幅飛び, 三段飛 } \\
\text { び, } 20 \mathrm{~km} \text { 競歩 }\end{array}$ & 全競技 \\
\hline カメラ & 19 台 & 9 台 & 7 台 & 6 台 & 6 台 \\
\hline VTR & $\begin{array}{c}\text { スロー4台 } \\
\text { スーパースロー } 1 \text { 台 }\end{array}$ & 4 台 & 4 台 & 3 台 & \\
\hline
\end{tabular}

* 各プロダクションからの信号を各競技の進行に従い切り替えて国際映像番組を制作する．このためIntegrate独自のカメラ、マイクを設け，きめ の細かい番組作りに対応している。 
また，トラック競技（プロダクション1）のカメラ 配置とフィールド競技のマイクポジションを図 3 , 図 4 に示す.

図 3 の No. 19 カメラは, 正面スタンドの屋根の下
にトラックと並行に取り付けられたレール上を高速で 移動できるワイヤレスリモコンカメラである（写真 3 , 写真 4).これは $100 \mathrm{~m}$ などのスタートからゴールま で走者とほほ同じ速度で移動しながら撮影するために

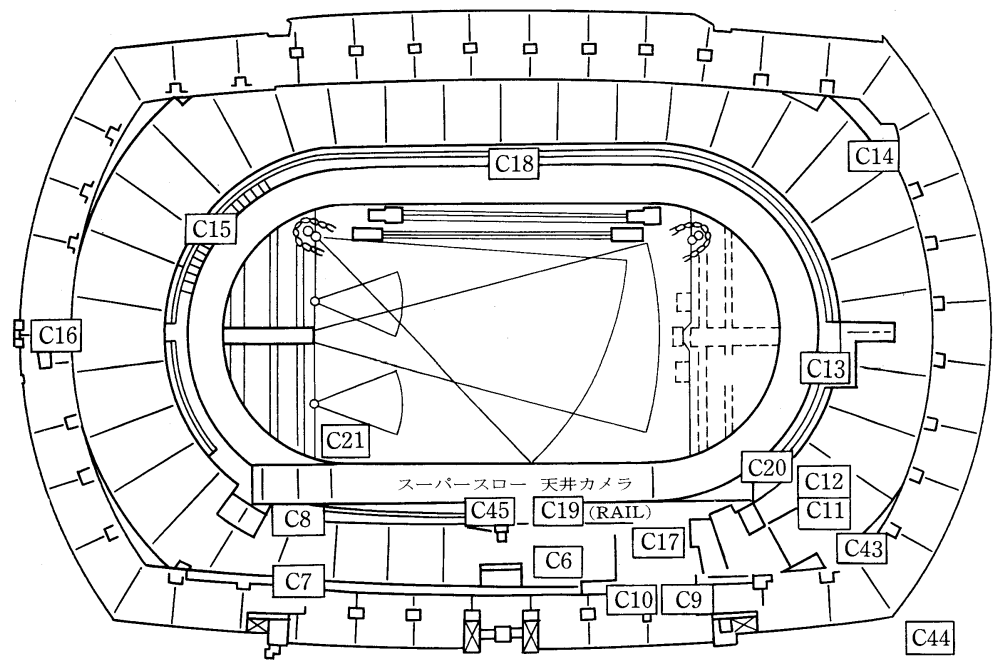

図 3 カメラ配置(トラック競技)

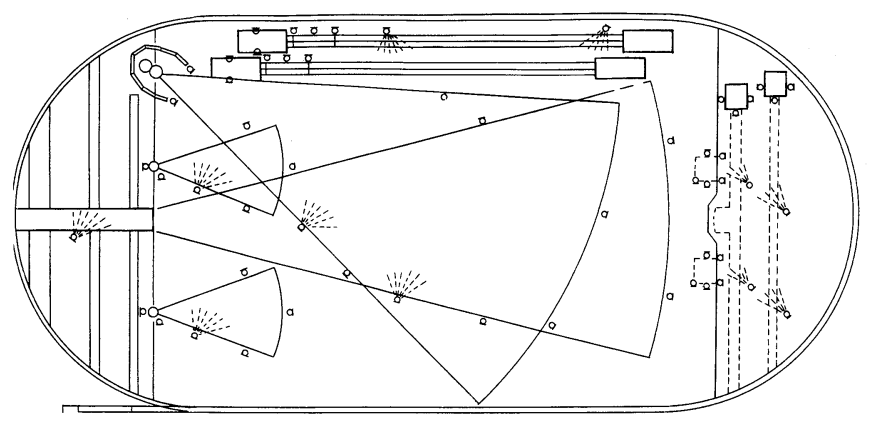

図 4 マイク配置(フィールド競技)

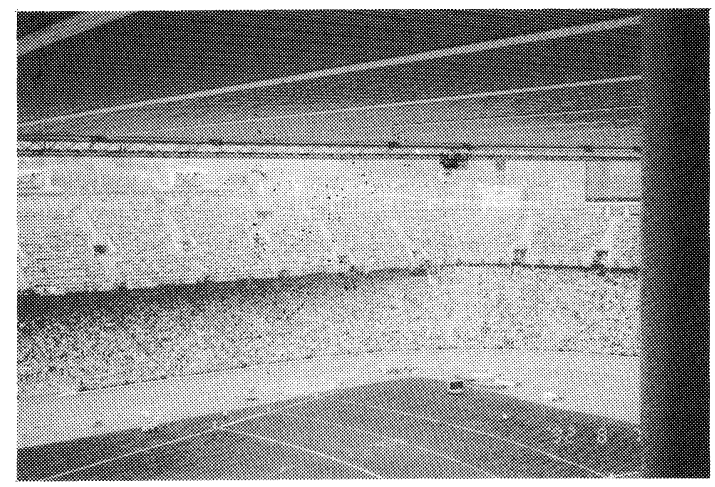

写真 3 高速移動カメラ

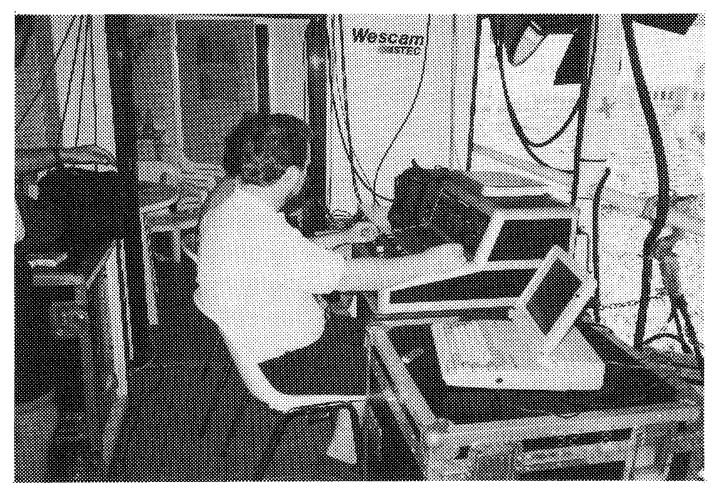

写真 4 高速移動カメラ制御部 
表 2 高速移動力メラ

\begin{tabular}{l|l}
\hline \hline トラック長 & $125 \mathrm{~m}$ \\
電源バー & $125 \mathrm{~m}$ \\
最大速度 & $12.5 \mathrm{~m} / \mathrm{sec}$ \\
最大加速 & $>6.5 \mathrm{~m} / \mathrm{s}^{2}$ \\
制御 & $\mathrm{VHF}$ \\
映像信号 & マイクロ波 \\
カメラ & $3 \mathrm{CCD}$ \\
システム担当 & $\mathrm{CTC}, \mathrm{WESCAM}$ \\
\hline
\end{tabular}

開発されたものである．競技だけでなく開閉会式でも 多用されて，その目新しい映像は大いに注目を集める こととなった？その移動システムの概要は表 2 のとお りである。

オフィシャルのスターターガンパルスをトリガーと してカメラをスタートできるなど，各種プログラム制 御が可能となっている.

\section{3. ヨット競技}

日本では，昨年行われたアメリカズ・カップ中継で のヨットレースの迫力ある空撮の映像が，一般視聴者 の関心を呼び起こしたことは記憶に新しいところであ る. GPSを利用した艇位置の CG 表示など，我が国 でもヨット競技の中継への取り組みはあるが，まだそ の機会は多くない，今回，バルセロナ大会で，オリン ピックでは初めてヨット競技が生中継されたので，こ こに中継の概要を紹介する.

競技は選手村近くの Port Olimpic の 5 つのエリア で，男女合わせて 11 のクラス，83のレースが 9 日間 にわたり行われた。 5 つのヨットコースのうち毎日 1 力所を生中継で分配し, 残りの 4 力所は “ENG” 制作 で対応した、ヨット競技中継は「ARD/ZDF」が担当し た. 2 つのプロダクション「TEAM $1 」, 「 E N G ・$ TEAM」が設けられ，各々の制作を分担した.

次に, 各プロダクションの概要を示す.

\section{TEAM 1}

カメラ

$\begin{array}{ll}\text { 船上 } & 4 \\ \text { ヘリコプタ } & 2 \\ \text { ブイ取り付け } & 2 \\ \text { 港内タワー } & 5 \\ \text { ミニカメラ (Soling boat) } & 4 \\ \text { VTR } & \\ \text { スロー用 } & 5 \\ \text { 編集用 } & 2 \text { セット } \\ \text { 他 } & 2\end{array}$

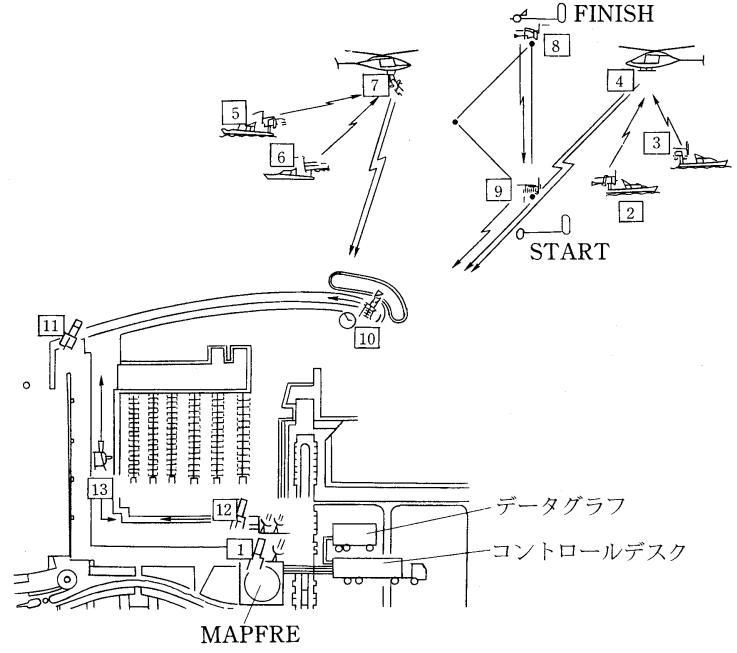

図 5 フリートレース時の配置

これらを 1 台の中継車で運用，表彰式を含め生中継 を制作した。

\section{ENG $\cdot$ TEAM}

$\begin{array}{ll}\text { カムコーダ } & 8 \\ \text { 取材用ボート } & 9 \\ \text { 編集セット } & 2 \\ \text { キャビン (Compound 内) } & 1\end{array}$

この体制で 4 つのコースの取材をカバーし編集し て, 毎日 IBCへの素材伝送 (Daily Summary) に対応 した，図 5 はフリートレースの時の配置である。

\section{4. 競 技 伝 送}

各競技の国際信号は通常 5 分前の競技開始アニメー

表 3 競技伝送開始フォーマット

\begin{tabular}{l|l|l}
\hline \hline Time & \multicolumn{1}{|c|}{} & Duration \\
\hline$-20^{\prime} 00^{\prime \prime}$ & Beauty Shots +ID & $14^{\prime} 57^{\prime \prime}$ \\
$-5^{\prime} 03^{\prime \prime}$ & Black & $3^{\prime \prime}$ \\
$-5^{\prime} 00^{\prime \prime}$ & Opening Animation & $20^{\prime \prime}$ \\
$-4^{\prime} 40^{\prime \prime}$ & Beauty Shots & $5^{\prime \prime}$ \\
$-4^{\prime} 35^{\prime \prime}$ & Location Graphics + Timetable & $30^{\prime \prime}$ \\
$-4^{\prime} 05^{\prime \prime}$ & Wide Clean Shots & $10^{\prime \prime}$ \\
$-3^{\prime} 55^{\prime \prime}$ & Weather Graphics & $15^{\prime \prime}$ \\
$-3^{\prime} 40^{\prime \prime}$ & Wide Clean Shots & $15^{\prime \prime}$ \\
$-3^{\prime} 25^{\prime \prime}$ & Event Title & $25^{\prime \prime}$ \\
$-3^{\prime} 00^{\prime \prime}$ & Wide Clean Shots & $20^{\prime \prime}$ \\
$-2^{\prime} 40^{\prime \prime}$ & World Record+Olympic Record & $20^{\prime \prime}$ \\
$-2^{\prime} 20^{\prime \prime}$ & Wide Clean Shots & $20^{\prime \prime}$ \\
$-2^{\prime} 00^{\prime \prime}$ & Lane Assignments + Individual List & $90^{\prime \prime}$ \\
$-' 30^{\prime \prime}$ & Wide Clean Shots & $30^{\prime \prime}$ \\
$00^{\prime} 00^{\prime \prime}$ & Sports Session Starts & \\
\hline
\end{tabular}


ションで始まるが, 表 3 のように, 回線には 20 分前 から競技種目や開始時間などの ID 信号が伝送され た. 競技終了後は, 競技結果や終了アニメーション等 を伝送し, 3 分後に終了した.

競技信号伝送の前後は 10 分単位で各局独自番組用 に回線を借用でき, 選手インタビューなどに使用され た。

\section{5. むす び}

「RTO’92」という混成チームで，これだけ大規模 なシステムをまとめあげたことには敬意を払うもので ある.D 3 ディジタル VTRの採用は画質の向上に貢 献した。また, 各会場でのステディカムやリモコンカ メラなど周辺器材の効果的な使用により, 質の高い番
組作りができたのは, 担当各局の経験がうまく生かさ れたといえよう。

(矢野)

(1992 年 9 月 28 日受付)

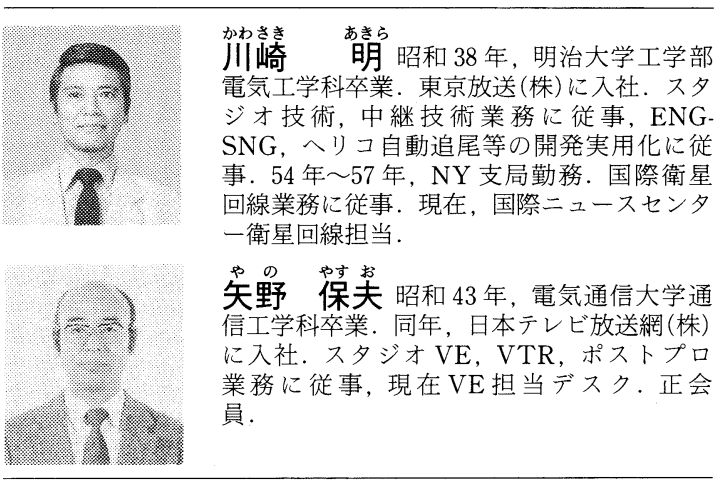

